\title{
Regurgitated ammonoid remains from the latest Devonian of Morocco
}

\author{
${\text { Christian } \mathrm{Klug}^{1} \text { (D) } \cdot \text { Lothar H. Vallon }}^{2}$
}

Received: 23 July 2018/Accepted: 12 October 2018/Published online: 26 October 2018

(C) Akademie der Naturwissenschaften Schweiz (SCNAT) 2018

\begin{abstract}
Accumulations of ammonoid shell fragments have been recovered from the Hangenberg Black Shale (latest Devonian) of the southern Maïder (eastern Anti-Atlas, Morocco). They are here interpreted as regurgitalites and ascribed tentatively to gnathostomes as possible tracemakers. The recognition of fossil regurgitations is reviewed and a checklist provided.
\end{abstract}

Keywords Ammonoidea $\cdot$ Mass extinctions $\cdot$ Hangenberg event $\cdot$ Chondichthyes $\cdot$ Food web $\cdot$ Digestichnia

\section{Introduction}

Regurgitalites (Hunt 1992) as well as coprolites and gastroliths are regarded as trace fossils according to Bertling et al. (2006). They are morphologically reoccurring structures that result from the live activity of an individual organism (or homotypic organisms) actively modifying a substrate. For coprolites and regurgitalites, the modified substrate consists of more or less (semi-) digested food and food parts (cf. Bertling et al. 2006; Vallon 2012).

Regurgitation may serve several purposes: Ridding the digestive tract of (1) poisonous or (2) mechanically dangerous matter or (3) feeding offspring (e.g., Grimm and Whitehouse 1963; Dodson and Wexlar 1979; Mund and Miller 1995; Keeling and Gonyou 2001; Queiroz and Rodríguez-Robles 2006). Regurgitating indigestible, hardly digestible or dangerous parts of prey organisms thus is a behaviour that is widespread or even ubiquitous among vertebrates from fish to mammals, but occurs also among invertebrates (Vallon 2012 and references therein). This behaviour is of palaeontological interest because, like stomach contents, cololites and coprolites, fossil

Editorial Handling: D. Marty.

Christian Klug

chklug@pim.uzh.ch

Lothar H. Vallon

kv@oesm.dk

1 Paläontologisches Institut und Museum, Karl Schmid-Strasse 4, 8006 Zurich, Switzerland

2 Geomuseum Faxe (Østsjællands Museum), Østervej 2, 4640 Faxe, Denmark regurgitates (regurgitalites) can help reconstructing food webs in deep time (e.g., Gilmore 1992; Aldridge et al. 2006; Argyriou et al. 2016). Also, these digestichnia may contain more or less articulated specimens of organisms that are otherwise not or only poorly known (e.g., Burrow and Turner 2010).

Regurgitalites (also dubbed pellets or Speiballen, see Thies and Hauff 2012) can be identified with some certainty when the structure contains prey parts that would normally be dissolved in the digestive tract such as thin aragonitic and calcitic structures (Schweigert 1999, 2018; Schweigert and Dietl 1999; Dietl and Schweigert 2011; Thies and Hauff 2012); nevertheless, since the amount of acids in digestive tracts varies between organisms, such objects might also survive digestion and thus become part of coprolites (e.g., Lehmann and Weitschat 1973; Mehl 1978; Lehmann 1983; Klug and Lehmann 2015). Additionally, damage (fractured hard parts) or even corrosion by acids in the stomach of the predator provides further support for the identification of regurgitalites (e.g., Zaton et al. 2007; Thies and Hauff 2012; Vallon 2012). By contrast, coprolites usually are dominated by a faecal groundmass, but regurgitalites rarely preserve any kind of matrix. If it is present, it might be preserved in a variety of substances including carbon, iron oxides, phosphates and others (Schweigert 1999, 2018). In contrast to coprolites, this matrix is usually more diffuse, less massive and forms rather a patch than a distinct three-dimensional structure.

Here, we describe three specimens from the Hangenberg Black Shale from the latest Devonian of the southern Maïder (eastern Anti-Atlas). They are less than $20 \mathrm{~mm}$ long, contain shell fragments and organic matter. These specimens were discovered in dark 
claystones of the Hangenberg Black Shale at Madene El Mrakib (South of Madène El Mrakib Klug et al. 2016; see also Becker et al. 2000), where these argillaceous layers are rich in ammonoids, bivalves and other fossils. Klug et al. (2016) described this Fossillagerstätte because it yielded well-preserved formerly chitinous jaw apparatuses of three ammonoid clades in association with the conchs.
The Maïder Basin is a small epicontinental sea (less than $100 \mathrm{~km}$ wide; Wendt 1985, 1988; Kaufmann 1998) that was located at the southern margin of the Prototethys (Scotese 1997; Kaiser et al. 2011) (see Fig. 1). Due to limited freshwater influx and submarine ridges east and west of this basin, oxygen contents of bottom water were low in the more central and deeper parts of the basin from the Givetian until the end of the Famennian. This is reflected in abundant haematitic fauna (formerly pyritized),

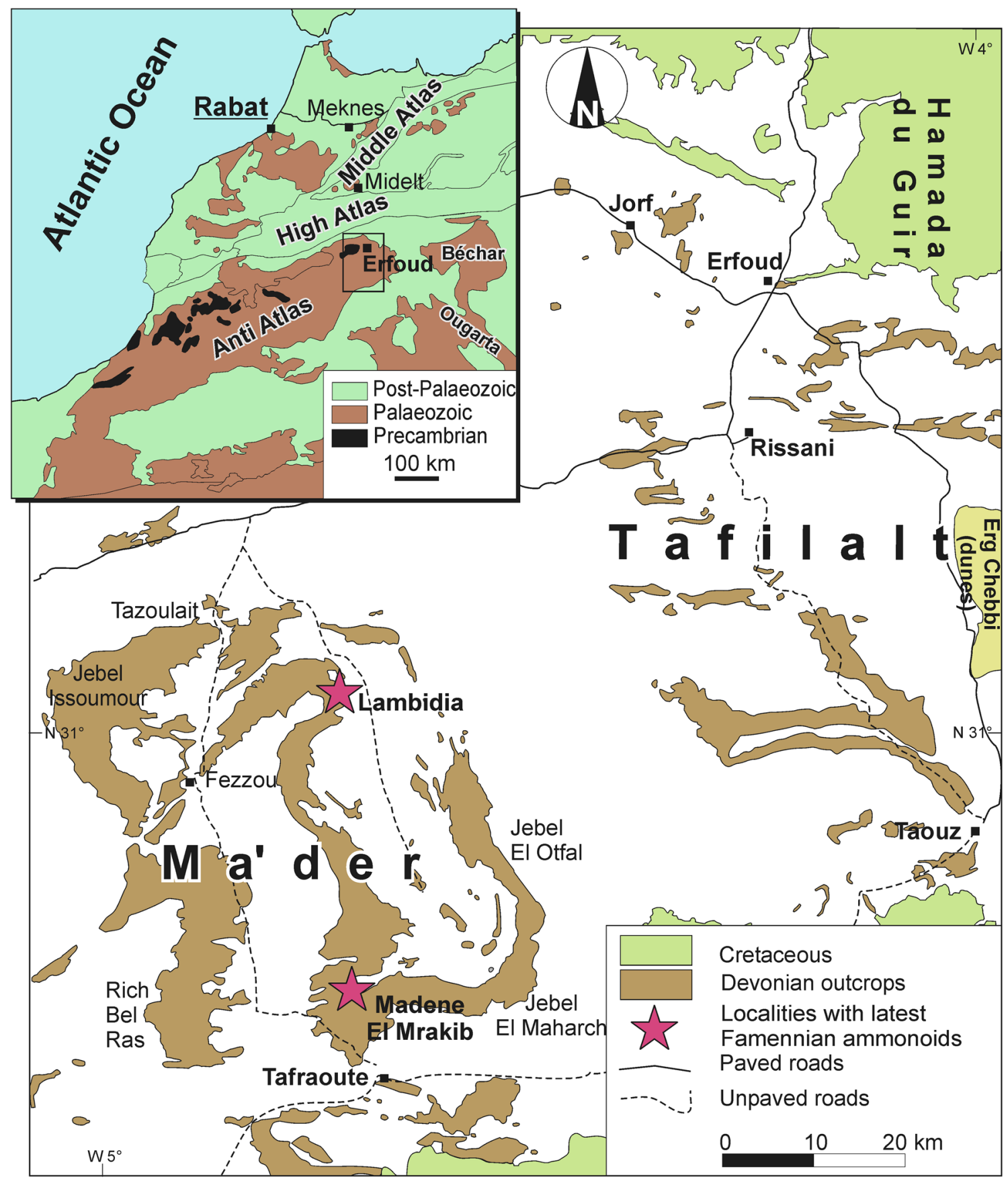

Fig. 1 Geological map of parts of the eastern Anti-Atlas with the locality Madene El Mrakib. Modified after Klug (2002) 
scarcity of benthic fauna and according trace fossils, the richness of iron oxides within the argillaceous sediment, and the preservation of complete skeletons of gnathostome fish (Frey et al. 2018). It is thus not surprising that organic rich argillaceous sediments were also deposited during the transgression that enabled the formation of the Hangenberg Black Shale. In Morocco, the Hangenberg Black Shale was described by several authors (Korn 1999; Kaiser et al. 2011, 2015; Klug et al. 2016; Becker et al. 2018; Frey et al. 2018). Besides the quite abundant bivalve genus Guerichia, three ammonoid taxa (Postclymenia, Mimimitoceras, Tornoeratidae indet.) were the most common invertebrates (Frey et al. 2018).

The global Hangenberg Event ranges among the most severe extinctions of the Palaeozoic (e.g., McGhee et al. 2013; McGhee 2014). Numerous important Metazoan clades including, e.g., the Phacopida, Clymeniida, Placodermi, Osteostraci, and Thelodonti became extinct (e.g., Klug et al. 2010; Sallan and Coates 2010; Sallan et al. 2011). After the end-Frasnian Kellwasser Event, this was the second devastating mass extinction that wiped out coral reefs and many shelf ecosystems, but also profoundly affected land ecosystems (e.g., Algeo et al. 1995, 2001; Algeo and Scheckler 1998; Kaiser et al. 2006, 2008, 2009, 2011, 2015; Becker et al. 2016). While the cause of this biodiversity crisis is widely debated (e.g., Jablonski 2001; MacLeod 1998, 2003, 2014; McGhee et al. 2013), rapid global climate and sealevel changes are documented in latest Devonian sedimentary successions such as in the eastern Anti-Atlas. In most parts of the Maïder Basin, argillaceous sediments rich in pyrite (weathering to haematite near the surface) with some carbonatic layers accumulated during much of the Famennian (Massa et al. 1965; Frey et al. 2018). Near the end of the Famennian, the carbonate content became further reduced during a global transgression and the fossil-bearing strata of the Hangenberg Black Shale were deposited. A global intense regression is documented worldwide by sandstones overlying the black shale in many sections (Haq and Schutter 2008; Kaiser et al. 2006, 2008, 2009, 2011, 2015; Becker et al. 2016).

In the following, we describe three small digestichnia specimens from the southern Maïder Basin; we discuss whether they represent coprolites or regurgitalites, the taxonomic affiliation of the shell fragments contained within, the potential producer and the implications for the latest Devonian food web in the Maïder Basin.

\section{Materials and methods}

Owing to today's arid climate with strong contrasts in temperatures and precipitation in the Anti-Atlas, the argillaceous sediments from the Famennian including the
Hangenberg Black Shale are deeply weathered (Klug et al. 2016). Its uppermost half metre has lost most of its organic matter. Fossils thus are difficult to recognise, also because they are strongly flattened. In most places, the Hangenberg Black Shale is covered by huge blocks of the Hangenberg Sandstone making direct access difficult. Where exposed, the weathered parts (usually light grey to almost whitish in colour) can easily be removed to access fresh sediment. Still, even at a depth of half a metre below the surface, the Hangenberg Black Shale breaks into slabs usually less than $100 \mathrm{~mm}$ wide. For most of the contained fossils, this poses no big problem because they are much smaller.

We recovered three specimens by splitting the very soft and laminated argillaceous sediment by hand, with a pocket knife or a hammer. These are stored in the Paläontologisches Institut und Museum of the Universität Zürich (PIMUZ numbers). One of the specimens was prepared with a needle. For comparison, an additional digestichnion (= coprolite?) is described which was collected from the Kimmeridgian plattenkalk (Beckeri Zone, lower layers of the Ulmense Subzone, rebouletianum Horizon, Torleite Formation) at the Rygol Quarry near the village Painten (Bavaria, Germany; see, e.g., Röper 2005; Klug et al. 2015).

\section{Descriptions}

Specimens PIMUZ 31570, 35200 and 35201 were all collected from the Hangenberg Black Shale (middle praesulcata conodont Zone: Kaiser et al. 2009; Cymaclymenia nigra ammonoid Zone: Becker et al. 2002; Korn and Klug 2015; Klug et al. 2016) at Madene El Mrakib. They are thus of latest Devonian age and preserved flattened on bedding planes in organic rich, laminated argillites full of small-sized Chondrites-burrows. All of the specimens shown in Fig. 2 contain imprints of shell fragments, which were completely dissolved as all calcareous structures are in these layers. Between these fragments, dark patches of carbon document tiny amounts of organic matter associated with these shell fragments. The shell fragments exhibit sharp edges and show no signs of etching (see below for clarification). This, however, could be a preservational bias because etching would only have affected the carbonatic parts of the shell fragments that have been dissolved during diagenesis and weathering.

Specimen PIMUZ 35200 (Figs. 2a, b, 3a) is $15 \mathrm{~mm}$ long and $7 \mathrm{~mm}$ wide. Both part and counterpart are depicted in Fig. 2a, b. This trace fossil contains numerous shell fragments (Fig. 3) of mostly less than $2 \mathrm{~mm}$ length. The single shards of this cluster vary in shape from rectangular via triangular to polygonal with most edges being more or less straight. Many of these fragments display lirae, which are 
Fig. 2 Three regurgitalites from the Famennian Hangenberg Black Shale of Madene El Mrakib. a, b Part and counterpart of PIMUZ 35200; note the lirae visible on some of the larger fragments and the associated fauna including bivalves, ammonitellae and an ammonoid jaw. c PIMUZ 31570 , most of the shell fragments show lirae. d Mimimitoceras sp., PIMUZ 31551; note the characteristic lirae and the lower jaw in the body chamber (from Klug et al. 2016: Fig. 3c). e PIMUZ 35201 , regurgitate with a somewhat greater size range of shell fragments, partially overlain by an isolated valve of a Guerichia elliptica
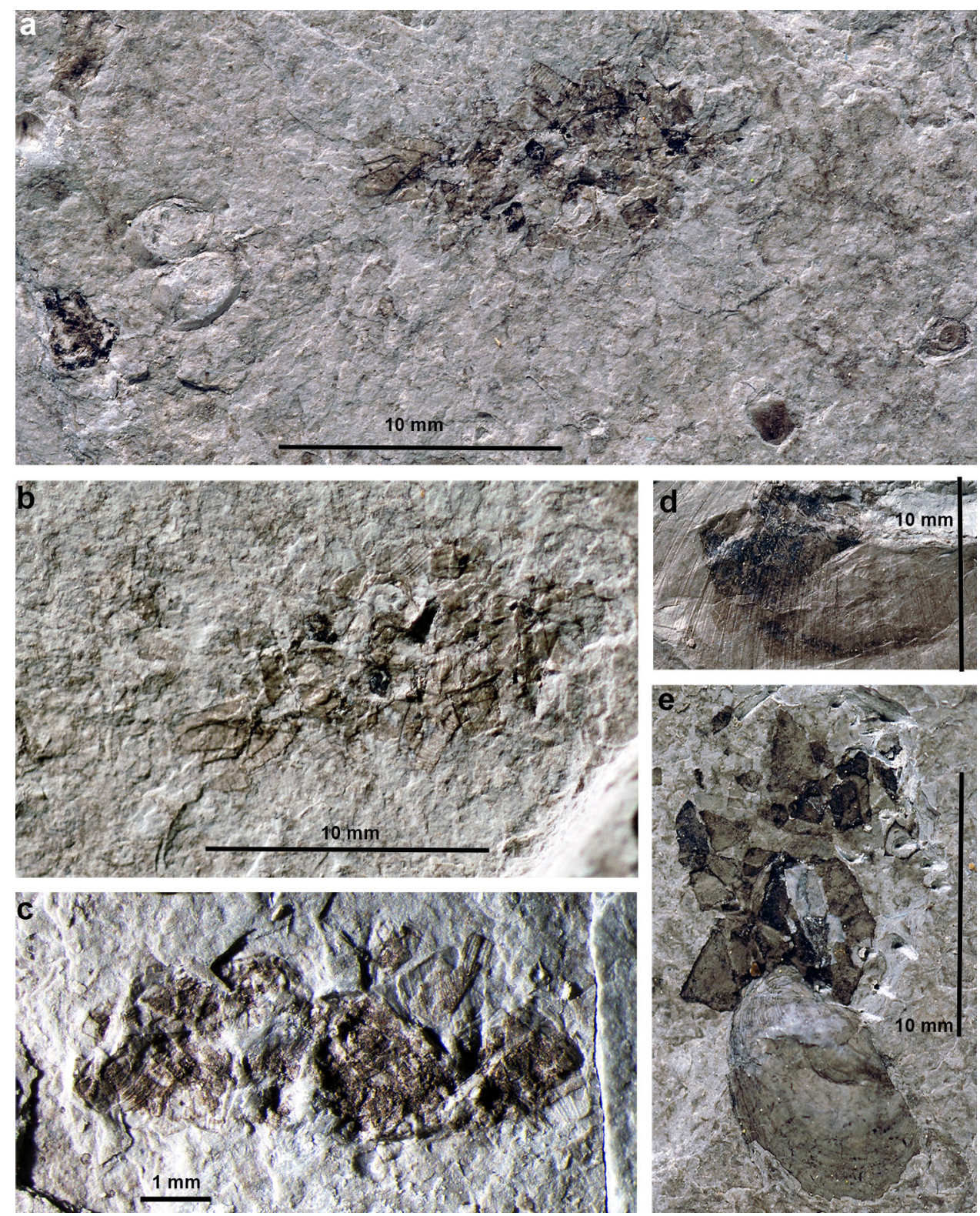

spaced at about $0.1 \mathrm{~mm}$. They appear as very fine and straight incised lines. A subcircular structure near the centre of the cluster appears coiled and might perhaps represent an embryonic conch of an ammonoid. Additionally, several black to dark grey spots measuring less than $1 \mathrm{~mm}$ are distributed irregularly between the shell fragments. Around this structure, an ammonoid jaw, articulated valves of a Guerichia, and ammonoid embryonic conchs are visible; however, these are likely associated by chance since they all occur commonly on the bedding planes.

Specimen PIMUZ 31570 (Fig. 2c) measures $8 \mathrm{~mm}$ in length and $3.5 \mathrm{~mm}$ in width. It is associated with a large ammonoid mandible described earlier by Klug et al. (Klug et al. 2016, Fig. 6g, h). Like specimen PIMUZ 35200, it contains many small shell fragments of less than $2 \mathrm{~mm}$ length, many of which preserved also with lirae. Overall, there is more organic material on and around the shards, giving the specimen a darker appearance.

Specimen PIMUZ 35201 (Fig. 2e) has the lowest number of shell fragments and measures about $11 \mathrm{~mm}$ in length and $9 \mathrm{~mm}$ in width. In this specimen, the shell fragments reach ca. $5 \mathrm{~mm}$ in size and have a dark appearance. One end of this fossil is overlain by a small bivalve.

Specimen PIMUZ 35202 (Figs. 3b, 4) is included here for comparison. It was collected from the organic-rich Kimmeridgian plattenkalk of Painten (Germany). This digestichnion has a more distinct outline, is $19 \mathrm{~mm}$ long 
a

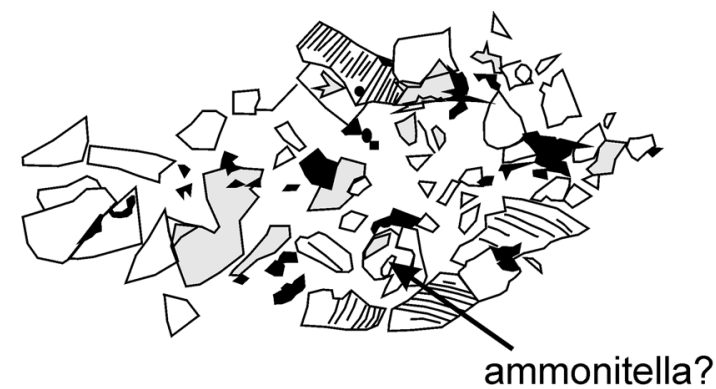

b

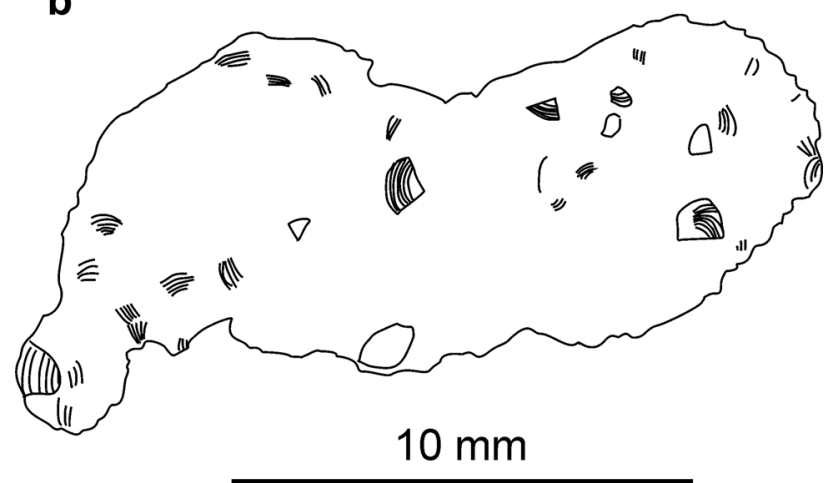

Fig. 3 Sketches of the regurgitalite shown in Fig. $2 \mathrm{a}$ and the questionable coprolite or regurgitalite of 4. a PIMUZ 35200, Hangenberg Black Shale, Famennian, Madene El Mrakib (Morocco); note the striation of some of the shell fragments and the questionable ammonitella (arrow); organic remains are shown in black. b PIMUZ 35202, Kimmeridgian, Painten (Germany); note the remains of at least 30 small ammonite aptychi, some of which are broken; the matrix is much thicker than in the Famennian regurgitalites

and $8 \mathrm{~mm}$ wide. In this case, the fossil contains numerous small fragmented calcitic aptychi, which measure less than $1 \mathrm{~mm}$. Its greyish brown to medium dark brown colour suggests that the film-like, thin matrix is phosphatic.

\section{Discussion}

\section{Taxonomic assignment of the shell fragments}

According to Frey et al. (2018), molluscs made up the trophic nucleus of the Hangenberg Black Shale at Madene El Mrakib. Besides the bivalve Guerichina, ammonoids are the most common group represented by Postclymenia, Mimimitoceras and an unidentified tornoceratid. Due to the preservation of lirae in most of the shell fragments, a direct comparison of these shell structures of the fragments with complete ammonoid conchs is possible. The lirae are very similar to those seen in Mimimitoceras. The conch ornamentation of the other two ammonoid taxa is less distinct and thus, it cannot be ruled out that members of these taxa are also included in the structures described herein. Nevertheless, only fragments of Mimimitoceras could be determined with some confidence.

\section{Coprolite or regurgitalite?}

Criteria how to distinguish coprolites from regurgitalites were presented and discussed independently from each other by Thies and Hauff (2012) and Vallon (2012). Coprolites are known from most of the Phanerozoic in large size ranges and different morphologies (e.g., Fisher 1981; Chin et al. 1998; Hunt et al. 2012). Their main component is either a phosphatic, calcitic or carbonaceous groundmass (Vallon 2012), but iron sulphides and oxides may also occur. This faecal groundmass has a macroscopically homogeneous appearance. Most fossil faeces are more or less elongate in the form of a sausage and some are shaped after the spiral guts which they had passed (Argyriou et al. 2016 and references therein). Especially larger coprolites that were produced by vertebrates may contain
Fig. 4 Regurgitalite (or coprolite?) from the Kimmeridgian, Painten (Germany); PIMUZ 35202; note the remains of at least 30 small ammonite aptychi and the more distinct outline due to the somewhat thicker matrix than in the Famennian regurgitalites

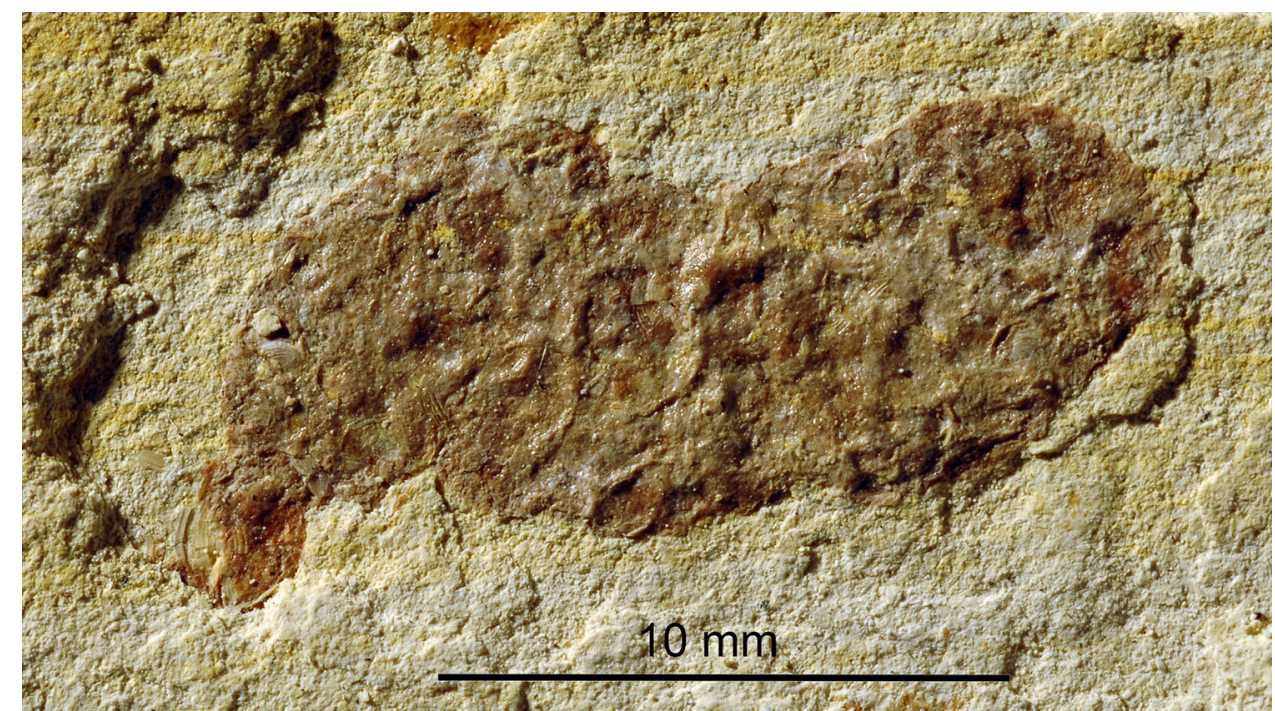


determinable prey remains (e.g., Fisher 1981; Chin et al. 1998; Milàn et al. 2012) and even intestinal parasites (e.g., Dodson and Wexlar 1979; Dentzien-Dias et al. 2013; De Baets and Littlewood 2015; Qvarnström et al. 2016).

Regurgitalites may be preserved in the same minerals as coprolites but usually lack a dominant groundmass. They often contain discernible remains of the prey organisms, such as hard parts or hardly digestible material, e.g. bones, shells, belemnite rostra, beaks, and aptychi (Figs. 3, 4), feathers, egg shells, hair, etc. (e.g., Thies and Hauff 2012; Vallon 2012). The main differences are the more irregular outline and the commonly nearly flat appearance (in contrast to recent casting pellets produced by birds). If a groundmass is present, it is much thinner than in coprolites, often rather a stain than a matrix, and macroscopically visible body parts of the prey are dominant (e.g., Schweigert 1999, 2018; Thies and Hauff 2012; Vallon 2012). This hard content may be partly fractured owing to chewing and biting or dissolution by the predator's stomach acids (Bochenski et al. 1993, 1998 and references to different birds therein). Signs of etching by stomach-acids like surface pitting (Hockett 1996; Sanz et al. 2001) are common and especially, around holes or fractures, the hard parts are often thinned out and the edges rounded (Bochenski et al. 1993, 1998; Hockett 1996). Furthermore, digestive enzymes and stomach acids may cause polishing, staining of bones (Hockett 1996 and references herein) and exfoliation (Andrews 1990). There is a large number of factors controlling the physical aspect of regurgitations, especially the etching patterns on hard body parts (cf. Hockett 1996). As an example, such factors may be the time interval between swallowing and regurgitation (Duke et al. 1976), the $\mathrm{pH}$ of the stomach solution (Duke et al. 1975) or the power of digestive enzymes (Hockett 1996). These factors were observed in pellet casting birds, but will most likely also be present in other groups (Vallon 2012). Although the carbonatic parts of the shell are no longer preserved in our case, they must have been present during the time the trace was made because fine details of the shell ornamentation are preserved. The presence of such carbonatic hard parts in the regurgitation suggests a relatively short retention time within the digestive tract (mouth, oesophagus or stomach). Even massive carbonatic objects can be entirely resolved in the stomach of many predators such as, e.g., crocodilians (Milàn 2012).

The stomach fluids and additional mucus bind the indigestible parts together and ease regurgitation. Even when Speiballen are expelled higher up in the water column, this slime will give the regurgitation considerable cohesion and prevents the hard parts from being scattered widely over the sea or lake floor (Vallon 2012). If partial etching by stomach fluids is not present, the binding mucus is the only criterion that separates fossil regurgitations from prey remains whose shells were just crushed and only their soft (= edible) bodyparts were ingested by the tracemaker. Without binding mucus, shell fragments will be scattered widely over the sediment surface when raining down from the water column. Recoveries of isolated shell fragments mainly from calm-water environments such as the Solnhofen Plattenkalks probably result from predation where the hard parts of the prey were not ingested (a potential explanation also for some belemnite accumulations according to Doyle and Macdonald 1993).

To recognise regurgitalites ("Speiballen"), at least several of the following criteria should be fulfilled (compiled and sorted after importance from Thies and Hauff 2012 and Vallon 2012):

1. Dominance of indigestible remains of at least one prey individual.

2. No or only minute amounts of a fine-grained matrix between the skeletal elements.

3. Hard content, like bones or (parts of) exoskeletons, can be partly or totally fractured due to chewing and biting.

4. Fractured and unfractured content of regurgitalites may show signs of etching by stomach-acids like surface pitting. Especially around holes or fractures, the bone tissue or shells are very often thinned out and the edges rounded. The articular ends of bones are often corroded.

5. The remains, if elongated, may be oriented parallel to each other or may be tightly packed (e.g. recent casting pellets of owls). In fossil examples, however, hard parts are commonly unoriented (in situ disaggregation by decay of binding material like felted hair or mucus); Arrangement or posture of prey remains are often different from their natural synvivo posture (e.g., coiling up of vertebral column).

6. Skeletal elements of the prey organism that may get lost easily by taphonomic processes (aptychi, skulls, etc.) are often present.

7. In contrast to hard body parts found in coprolites, regurgitated material is often bigger in size and articulated hard body parts occur more often.

8. Digestive enzymes and stomach acids may cause polishing and staining of indigestible parts as well as exfoliation.

9. Stomach fluids and additional mucus that ease regurgitation of the indigestible material are binding together the more or less loose parts. Even when regurgitated higher up in the water column this slime probably gives the regurgitation considerable cohesion and prevents the hard parts from being scattered widely over the sea or lake floor. 
10. Accumulations exhibit a sharp boundary with an irregular outline towards the surrounding sediment, which was caused by the adhesive organic slime binding together the indigestible, regurgitated parts;

11. Skeletal materials that become dissolved easily (egg shells, cephalopod conchs, aptychi) when passing through the entire digestive tract of the predator are preserved. For example, the contents preserved in ammonoid digestive tracts differ from the prey remains in supposed ammonoid coprolites (e.g., Janicke 1970; Mehl 1978).

12. Fossil examples are mainly known from calm-water environments or caves (see Abel 1935, p. 317).

The Famennian fossils that are object of this study are preserved as flat structures. This probably corresponds to their prediagenetic state, because there is not a lot of material between the shell fragments present. Nevertheless, almost all fossils in the Hangenberg Black Shale of the Maïder Basin are flattened by compaction of the argillaceous sediments (Klug et al. 2016). Second, the only discernible prey parts contained in these regurgitalites are shell fragments of ammonoid conchs. These would have been dissolved in the digestive tract of the predator if they had passed its entire digestive tract and thus spent a prolonged time exposed to the acids therein (cf. Wings and Sander 2007; cf. Milàn 2012). We conclude therefore that, according to the indications listed above, the three Famennian specimens likely represent regurgitalites.

\section{Who ate the ammonoids?}

Independent of the answer to the question whether the fossil structures discussed here represent coprolites or regurgitalites, the question for a predator capable of crushing ammonoid conchs arises. As shown by Lemanis et al. (2016), the constructional morphology of ammonoid conchs was not only suited to withstand the hydrostatic pressure of hundreds of metres of water depth (e.g., Westermann 1973, 1985; Westermann and Ward 1980; Hewitt and Westermann 1986, 1987; Hewitt 1996; Hassan et al. 2002) but the septa helped to withstand point loads such as those exerted by pointed teeth of jawed predators. Consequently, the culprit who broke the shells must have had jaws (cf. Klug et al. 2017) or comparable structures capable to exert enough pressure to break ammonoid conchs. More or less convincing evidence for predation attempts on ammonoids was provided for predators among other cephalopods (Mehl 1978; Kruta et al. 2011; Keupp 2012; Tanabe et al. 2013; Ritterbush et al. 2014; Klug and Lehmann 2015), arthropods (e.g., Keupp 2000, 2012; Brett and Walker 2002), chondrichthyans (e.g., Vullo 2011), actinopterygians (e.g., Martill 1990; Klompmaker et al.
2009; Richter 2009; Ritterbush et al. 2014) and marine reptiles (Fenton and Fenton 1958; Seilacher 1998; Tsujita \& Westermann 2001).

Which of these groups could have supplied the tracemaker of the regurgitalites? Ammonoids that inhabited the Mäider Basin during the latest Famennian were all rather small with diameters usually between $1 \mathrm{~mm}$ (hatchlings) and about $50 \mathrm{~mm}$ (adults; Klug et al. 2016). The shell fragments in the regurgitalites point at ammonoid conch sizes corresponding to the largest ammonoids occurring in these strata, so this appears to be unlikely. The only arthropod remains found thus far in the Hangenberg Black Shale are small ostracods and one eurypterid leg (unpublished). However, phyllocarids have rarely been reported from the Famennian of the Maïder (Frey et al. 2018), but they do occur in several layers and it is well conceivable that they also lived in the Maïder during the latest Famennian. It can also not be ruled out that they fed on ammonoids with their strong mandibles (cf. Klug et al. 2008), although it has been suggested that they were rather benthic (Bergström et al. 1987; Rust et al. 2016). In any case, there is no evidence for their presence in the Hangenberg Black Shale of the Maïder yet. As far as jawed fish are concerned, the culprit rather is a chondrichthyan than an actinopterygian or sarcopterygian, because the latter two groups have not yet been documented in or stratigraphically near to the Hangenberg Black Shale of the Maider while some isolated chondrichthyan teeth and one small lower jaw (undescribed) have been recovered (Klug et al. 2016, Fig. 7f). These teeth are multicuspid with curved and slender cusps, which makes a durophagous diet of these gnathostomes unlikely (e.g., Whitenack et al. 2011) unless they were part of a heterodont dentition, which, however, appears equally unlikely (Burrow and Turner 2010). Furthermore, multicuspid teeth would have left holes, depressions and scratchings on the ammonoid shell fragments and the edges of the fragments would be rather jagged than straight (Martill 1990; Mapes \& Chaffin 2003; Vullo 2011). In the absence of discoveries of remains of durophagous fish, we suggest that there were predatory gnathostomes in the Maïder Basin capable of crushing ammonoid conchs. Perhaps, future excavations will reveal remains of the culprit. In any case, it is usually impossible to find direct evidence for the producer of regurgitalites.

\section{The fossil record of regurgitalites}

To our knowledge, the oldest regurgitalites documented so far are of Early Devonian (Burrow and Turner 2010; Thies and Hauff 2012) and Carboniferous age (Zangerl and Richardson 1963; Pollard 1990), although there are certainly older ones (e.g., Aldridge et al. 2006; Burrow and Turner 2010). This is somewhat surprising because it 
appears likely that most gnathostome vertebrates were capable of regurgitating stomach contents. From the Mesozoic, several regurgitalites have been reported, among which some with cephalopod remains (Schweigert 1999, 2018). If our interpretation of the herein described Famennian specimens as regurgitalites is correct, they would represent the oldest regurgitalites containing cephalopod remains recorded to date.

\section{Conclusions}

Three accumulations of ammonoid shell fragments from the Hangenberg Black Shale of the southern Maïder Basin (eastern Anti-Atlas, Morocco) are interpreted as regurgitalites, probably made by a gnathostome fish although fossils of such a predator have not been recovered from these strata, yet. If our interpretation is correct, these accumulations of shell fragments represent the oldest examples of fossil regurgitalites containing cephalopod remains and also of ammonoids that were successfully preyed upon.

Additionally, we provide a list of criteria to identify regurgitalites emended from Thies and Hauff (2012) and Vallon (2012). This list is possibly not comprehensive yet but will hopefully help others to identify regurgitalites better in the future.

Acknowledgements We greatly appreciate the support by the Swiss National Science Foundation (Project Numbers 200020_132870, 200020_149120,200021_156105). We thank the Ministère de l'Energie, des Mines, de l'Eau et de l'Environnement (Direction du Développement Minier, Division du Patrimoine, Rabat, Morocco) for working and sample export permits. We acknowledge the thorough reviews of Kenneth De Baets (Erlangen) and an anonymous reviewer that helped to improve the current paper.

\section{References}

Abel, O. (1935). Vorzeitliche Lebensspuren. Jena: Fischer.

Aldridge, R. J., Gabbott, S. E., Siveter, L. J., \& Theron, J. N. (2006). Bromalites from the Soom Shale Lagerstätte (Upper Ordovician) of South Africa: Palaeoecological and palaeobiological implications. Palaeontology, 49, 857-871.

Algeo, T. J., Berner, R. A., Maynard, J. B., \& Scheckler, S. E. (1995). Late Devonian oceanic anoxic events and biotic crises: 'rooted' in the evolution of vascular plants. GSA Today, 5, 63-66.

Algeo, T. J., \& Scheckler, S. E. (1998). Terrestrial-marine teleconnections in the Devonian: links between the evolution of land plants, weathering processes, and marine anoxic events. Philosophical Transactions of the Royal Society of London, (B): Biological Sciences, 353, 113-130.

Algeo, T. J., Scheckler, S. E., \& Maynard, J. B. (2001). Effects of Middle to Late Devonian spread of vascular land plants and weathering regimes. In P. G. Gensel \& D. Edwards (Eds.), Plants invade the land (pp. 213-237). New York: Columbia University Press.
Andrews, P. (1990). Owls, caves and fossils: predation, preservation and accumulation of small mammal bones in caves, with an analysis of the Pleistocene cave faunas from Westbury-SubMendip, Somerset, UK. London: University of Chicago Press.

Argyriou, T., Clauss, M., Maxwell, E. E., Furrer, H., \& SánchezVillagra, M. R. (2016). Exceptional preservation reveals gastrointestinal anatomy and evolution in early actinopterygian fishes. Scientific Reports, 6, 18758.

Becker, R. T., Bockwinkel, J., Ebbighausen, V., \& House, M. R. (2000). Jebel Mrakib, Anti-Atlas (Morocco), a potential Upper Famennian substage boundary stratotype section. Notes et Mémoires, Service des Mines et de la carte géologique du Maroc, 399, 75-86.

Becker, R. T., Hartenfels, S., Klug, C., Aboussalam, Z. S., \& Afhüppe, L. (2018). The cephalopod-rich Famennian and Tournaisian of the Aguelmous Syncline (southern Maïder). Münstersche Forschungsberichte zur Geologie und Paläontologie, 110(1), 273-306.

Becker, R. T., House, M. R., Bockwinkel, J., Ebbighausen, V., \& Aboussalam, Z. S. (2002). Famennian ammonoid zones of the eastern Anti-Atlas (southern Morocco). Münstersche Forschungen zur Geologie und Paläontologie, 93, 159-205.

Becker, R. T., Kaiser, S. I., \& Aretz, M. (2016). Review of chrono-, litho- and biostratigraphy across the global Hangenberg Crisis and Devonian-Carboniferous boundary. Geological Society of London, Special Publications, 423, 355-386. https://doi.org/10. 1144/SP423.10.

Bergström, J., Briggs, D. E. G., Dahl, E., Rolfe, W. D. I., \& Stürmer, W. (1987). Nahecaris stuertzi, a phyllocarid crustacean from the Lower Devonian Hunsrück Slate. Paläontologische Zeitschrift, 61, 273-298.

Bertling, M., Braddy, S. J., Bromley, R. G., Demathieu, G. R., Genise, J., Mikuláš, R., et al. (2006). Names for trace fossils: A uniform approach. Lethaia, 39, 265-286.

Bochenski, Z. M., Huhtala, K., Jussila, P., Pulliainen, E., Tornberg, R., \& Tunkkari, P. S. (1998). Damage to bird bones in pellets of Gyrfalcon Falco rusticolus. Journal of Archaeological Science, 25, 425-433.

Bochenski, Z. M., Tomek, T., Boev, Z., \& Mitev, I. (1993). Patterns of birdbone fragmentation in pellets of the tawny owl (Strix aluco) and the eagle owl (Bubo bubo) and their taphonomic implications. Acta Zoologica Cracoviensia, 36, 313-328.

Brett, C. E., \& Walker, S. E. (2002). Predators and predation in Paleozoic marine environments. Paleontological Society Papers, 8, 93-118

Burrow, C., \& Turner, S. (2010). Reassessment of "Protodus scoticus" from the Early Devonian of Scotland. In K. Elliot, J. G. Maisey, X. Yu, \& D. Miao (Eds.), Morphology, phylogeny and palaeobiogeography of fossil fishes (pp. 123-144). Munich: Pfeil.

Chin, K., Tokaryk, T. T., Erickson, G. M., \& Calk, L. C. (1998). A king-sized theropod coprolite. Nature, 393, 680-682.

De Baets, K., \& Littlewood, D. T. J. (2015). The importance of fossils in understanding the evolution of parasites and their vectors. Advances in Parasitology, 90, 1-51.

de Queiroz, A., \& Rodríguez-Robles, J. A. (2006). Historical contingency and animal diets: The origins of egg eating in snakes. American Naturalist, 167, 684-694.

Dentzien-Dias, P. C., Poinar, G., de Figueiredo, A. E. Q., Pacheco, A. C. L., Horn, B. L. D., \& Schultz, C. L. (2013). Tapeworm eggs in a 270 million-year-old shark coprolite. PLoS ONE, 8(1), e55007. https://doi.org/10.1371/journal.pone.0055007.

Dietl, G., \& Schweigert, G. (2011). Im Reich der Meerengel Fossilien aus dem Nusplinger Plattenkalk (2. Auf.). Munich: Pfeil. 
Dodson, P., \& Wexlar, D. (1979). Taphonomic investigations of owl pellets. Paleobiology, 5, 275-284.

Doyle, P., \& Macdonald, D. I. M. (1993). Belemnite battlefields. Lethaia, 26, 65-80.

Duke, G. E., Evanson, O. A., \& Jegers, A. (1976). Meal to pellet intervals in 14 species of captive raptors. Comparative Biochemistry and Physiology, 53A, 1-6.

Duke, G. E., Jegers, A. A., Loff, G., \& Evanson, O. A. (1975). Gastric digestion in some raptors. Comparative Biochemistry and Physiology, 50A, 649-656.

Fenton, C. L., \& Fenton, M. A. (1958). The fossil book (p. 482). New York: Doubleday.

Fisher, D. C. (1981). Crocodilian scatology, microvertebrate concentrations, and enamel-less teeth. Paleobiology, 7, 262-275.

Frey, L., Rücklin, M., Korn, D., \& Klug, C. (2018). Late Devonian and Early Carboniferous alpha diversity, ecospace occupation, vertebrate assemblages and bio-events of southeastern Morocco. Palaeogeography, Palaeoclimatology, Palaeoecology, 496, $1-17$.

Gilmore, B. (1992). Scroll coprolites from the Silurian of Ireland and the feeding of early vertebrates. Palaeontology, 35, 319-333.

Grimm, R., \& Whitehouse, W. M. (1963). Pellet formation in a Great Horned Owl: A roentgenographic study. The Auk, 80, 301-306. https://doi.org/10.2307/4082889.

Haq, B. U., \& Schutter, S. R. (2008). A chronology of Paleozoic sealevel changes. Science, 322, 64-68.

Hassan, M. A., Westermann, G. E. G., Hewitt, R. A., \& Dokainish, M. A. (2002). Finite-element analysis of simulated ammonoid septa (extinct Cephalopoda): septal and sutural complexities do not reduce strength. Paleobiology, 28, 113-126. https://doi.org/10. 1666/0094-8373(2002)028\%3c0113:feaosa\%3e2.0.co;2.

Hewitt, R. A. (1996). Architecture and strength of the ammonoid shell. In N. H. Landman, Tanabe, K., \& Davis, R. A. (Eds.), Ammonoid paleobiology. Topics in Geobiology, 13, 297-339.

Hewitt, R. A., \& Westermann, G. E. G. (1986). Function of complexly fluted septa in ammonoid shells. I. Mechanical principles and functional models. Neues Jahrbuch für Geologie und Paläontologie Abhandlungen, 172, 47-69.

Hewitt, R. A., \& Westermann, G. E. G. (1987). Function of complexly fluted septa in ammonoid shells II. Septal evolution and conclusions. Neues Jahrbuch für Geologie und Paläontologie Abhandlungen, 174, 135-169.

Hockett, B. S. (1996). Corroded, thinned and polished bones created by golden eagles (Aquila chrysaetos): Taphonomic implications for archaeological interpretations. Journal of Archaeological Science, 23, 587-591.

Hunt, A. P. (1992). Late Pennsylvanian coprolites from the Kinney Brick Quarry, central New Mexico, with notes on the classification und utility of coprolites. New Mexico Bureau of Mines and Mineral Resources, Bulletin, 138, 221-229.

Hunt, A. P., Milàn, J., Lucas, S. G., \& Spielmann, J. A. (Eds., 2012). Vertebrate coprolites. New Mexico Museum of Natural History and Science, Bulletin, 57, 1-387.

Jablonski, D. (2001). Lessons from the past: evolutionary impacts and mass extinctions. Proceedings of the National Academy of Science, USA, 98, 5393-5398.

Janicke, V. (1970). Lumbricaria - ein Cephalopoden-Koprolith. Neues Jahrbuch für Geologie und Paläontologie Monatshefte, 3, $50-60$.

Kaiser, S. I., Aretz, M., \& Becker, R. T. (2015). The global Hangenberg Crisis (Devonian-Carboniferous transition): review of a first-order mass extinction. Geological Society of London, Special Publications, 423, 51. https://doi.org/10.1144/SP423.9.

Kaiser, S. I., Becker, R. T., Spalletta, C., \& Steuber, T. (2009). Highresolution conodont stratigraphy, biofacies, and extinctions around the Hangenberg Event in pelagic successions from
Austria, Italy, and France. Palaeontographica Americana, 63, 97-139.

Kaiser, S. I., Becker, R. T., Steuber, T., \& Aboussalam, Z. S. (2011). Climate-controlled mass extinctions, facies, and sea-level changes around the Devonian-Carboniferous boundary in the eastern Anti-Atlas (SE Morocco). Palaeogeography, Palaeoclimatology, Palaeoecology, 310, 340-364.

Kaiser, S. I., Steuber, T., \& Becker, R. T., (2008). Environmental change during the Late Famennian and Early Tournaisian (Late Devonian-Early Carboniferous) - implications from stable isotopes and conodont biofacies in southern Europe. In M. Aretz, H.-G. Herbig, \& I. D. Somerville (Eds.) Carboniferous platforms and Basins. Geological Journal, 43, 241-260.

Kaiser, S. I., Steuber, T., Becker, R. T., \& Joachimski, M. M. (2006). Geochemical evidence for major environmental change at the Devonian-Carboniferous boundary in the Carnic Alps and the Rhenish Massif. Palaeogeography, Palaeoclimatology, Palaeoecology, 240, 146-160.

Kaufmann, B. (1998). Facies, stratigraphy and diagenesis of Middle Devonian reef- and mud-mounds in the Mader (eastern AntiAtlas, Morocco). Acta Geologica Polonica, 48, 43-106.

Keeling, L. K., \& Gonyou, H. W. (Eds.). (2001). Social behaviour in farm animals. New York: CABI Publishing.

Keupp, H. (2000). Ammoniten - paläobiologische Erfolgsspiralen. Stuttgart: Jan Thorbecke Verlag.

Keupp, H. (2012). Atlas zur Paläopathologie der Cephalopoden. Berliner Paläobiologische Abhandlungen, 12, 1-392.

Klompmaker, A. A., Waljaard, N. A., \& Fraaije, R. H. B. (2009). Ventral bite marks in Mesozoic ammonoids. Palaeogeography, Palaeoclimatology, Palaeoecology, 280, 245-257.

Klug, C., Frey, L., Korn, D., Jattiot, R., \& Rücklin, M. (2016). The oldest Gondwanan cephalopod mandibles (Hangenberg Black Shale, Late Devonian) and the mid-Palaeozoic rise of jaws. Palaeontology, 59, 611-629.

Klug, C. (2002). Quantitative stratigraphy and taxonomy of late Emsian and Eifelian ammonoids of the eastern Anti-Atlas (Morocco). Courier Forschungsinstitut Senckenberg, 238, 1-109.

Klug, C., Frey, L., Pohle, A., De Baets, K., \& Korn, D. (2017). Palaeozoic evolution of animal mouthparts. Bulletin of Geosciences, 92, 511-524.

Klug, C., Fuchs, D., Schweigert, G., Röper, M., \& Tischlinger, H. (2015). New anatomical information on arms and fins from exceptionally preserved Plesioteuthis (Coleoidea) from the Late Jurassic of Germany. Swiss Journal of Palaeontology, 134, 245-255. https://doi.org/10.1007/s13358-015-0093-y.

Klug, C., Kröger, B., Kiessling, W., Mullins, G. L., Servais, T., Frýda, J., et al. (2010). The Devonian nekton revolution. Lethaia, 43, 465-477.

Klug, C., Kröger, B., Rücklin, M., Korn, D., Schemm-Gregory, M., De Baets, K., et al. (2008). Ecological change during the early Emsian (Devonian) in the Tafilalt (Morocco), the origin of the Ammonoidea, and the first African pyrgocystid edrioasteroids, machaerids and phyllocarids. Palaeontographica A, 283, 1-94.

Klug, C., \& Lehmann, J. (2015). Soft part anatomy of ammonoids: reconstructing the animal based on exceptionally preserved specimens and actualistic comparisons. In C. Klug, D. Korn, K. Baets, I. Kruta, \& R. H. Mapes (Eds.), Ammonoid paleobiology, volume I: from anatomy to ecology. Topics in geobiology (Vol. 43, pp. 539-552). Dordrecht: Springer.

Korn, D. (1999). Famennian ammonoid stratigraphy of the Máder and Tafilalt (eastern Anti-Atlas, Morocco). Abhandlungen der Geologischen Bundesanstalt, 54, 147-179.

Korn, D., \& Klug, C. (2015). Paleozoic ammonoid stratigraphy. In C. Klug, D. Korn, K. De Baets, I. Kruta, \& R. H. Mapes (Eds.), Ammonoid paleobiology, volume I: from anatomy to ecology. 
topics in geobiology (Vol. 43, pp. 299-328). Dordrecht: Springer.

Kruta, I., Landman, N., Rouget, I., Cecca, F., \& Tafforeau, P. (2011). The role of ammonites in the mesozoic marine food web revealed by jaw preservation. Science, 331, 70-72.

Lehmann, U. (1983). Jaws, Radula and Crop of Arnioceras (Ammonoidea). Palaeontology, 14, 338-341.

Lehmann, U., \& Weitschat, W. (1973). Zur Anatomie und Ökologie von Ammoniten: Funde von Kropf und Kiemen. Paläontologische Zeitschrift, 47, 69-76.

Lemanis, R., Zachow, S., \& Hoffmann, R. (2016). Comparative cephalopod shell strength and the role of septum morphology on stress distribution. PeerJ, 4(e2434), 1-20. https://doi.org/10. 7717/peerj.2434.

MacLeod, N. (1998). Impacts and marine invertebrate extinctions. Geological Society of London, Special Publications, 140, 217-246.

MacLeod, N. (2003). The causes of Phanerozoic extinctions. In L. J. Rothschild \& A. Lister (Eds.), Evolution on planet earth: The impact of the physical environment (pp. 253-277). Amsterdam: Academic Press.

MacLeod, N. (2014). The geological extinction record: History, data, biases, and testing. Geological Society of America, Special Paper, 505, 1-28. https://doi.org/10.1130/2014.2505(01).

Mapes, R., \& Chaffin, D. (2003). Predation on cephalopods. In P. Kelley, M. Kowalewski, \& T. Hansen (Eds.), Predator-prey interactions in the fossil record (pp. 177-213). New York: Springer.

Martill, D. M. (1990). Predation on Kosmoceras by semionotid fish in the middle Jurassic lower Oxford clay of England. Palaeontology, 33, 739-742.

Massa, D., Combaz, A., \& Manderscheid, G. (1965). Observations sur les séries siluro-dévoniennes des confins algéro-marocains du Sud. Notes et Mémoires, Compagnie Française des Pétroles, 8 , $1-188$.

McGhee, G. R., Jr. (2014). When the invasion of land failed. The legacy of the Devonian ex- tinctions. New York: Columbia University Press.

McGhee, G. R., Jr., Clapham, M. E., Sheehan, P. M., Bottjer, D. J., \& Droser, M. L. (2013). A new ecological-severity ranking of major Phanerozoic biodiversity crises. Palaeogeography, Palaeoclimatology, Palaeoecology, 370, 260-270.

Mehl, J. (1978). Ein Koprolith mit Ammoniten-Aptychen aus dem Solnhofer Plattenkalk. Jahresberichte der Wetterauischen Gesellschaft fuer die gesamte Naturkunde, 129(130), 75-93.

Milàn, J. (2012). Crocodylian scatology—A look into morphology, internal architecture, inter- and intraspecific variation and prey remains in extant crocodylian feces. New Mexico Museum of Natural History and Science, Bulletin, 57, 65-71.

Milàn, J., Rasmussen, B. W., \& Lynnerup, N. (2012). A coprolite in the MDCT-Scanner - Internal Architecture and bone contents revealed. New Mexico Museum of Natural History and Science, Bulletin, 57, 99-102.

Mund, M. J., \& Miller, G. D. (1995). Diet of the south polar skua Catharacta maccormicki at Cape Bird, Ross Island, Antarctica. Polar Biology, 15, 453-455.

Pollard, J. E. (1990). Evidence for diet. In D. E. G. Briggs \& P. R. Crowther (Eds.), Palaeobiology: a synthesis (pp. 362-367). Oxford: Blackwell.

Qvarnström, M., Niedźwiedzki, G., \& Žigaitè, Ž. (2016). Vertebrate coprolites (fossil faeces): An underexplored Konservat-Lagerstätte. Earth-Science Reviews, 162, 44-57.

Richter, A. E. (2009). Ammoniten-Gehäuse mit Bissspuren. Berliner Paläobiologische Abhandlungen, 10, 297-305.

Ritterbush, K. A., Hoffmann, R., Lukeneder, A., \& De Baets, K. (2014). Pelagic palaeoecology: The importance of recent constraints on ammonoid palaeobiology and life history. Journal of Zoology, 292, 229-241.

Röper, M. (2005). East Bavarian Plattenkalk-different types of upper Kimmeridgian to lower Tithonian Plattenkalk deposits and facies. Zitteliana, 26, 57-70.

Rust, J., Bergmann, A., Bartels, C., Schoenemann, B., Sedlmeier, S., \& Kühl, G. (2016). The Hunsrück biota: A unique window into the ecology of Lower Devonian arthropods. Arthropod Structure \& Development, 45, 140-151.

Sallan, L. C., \& Coates, M. I. (2010). End-Devonian extinction and a bottleneck in the early evolution of modern jawed vertebrates. Proceedings of the National Academy of Sciences, 107, 10131-10135.

Sallan, L. C., Kammer, T. W., Ausich, W. I., \& Cook, L. A. (2011). Persistent predator-prey dynamics revealed by mass extinction. Proceedings of the National Academy of Sciences, 108(20), 8335-8338.

Sanz, J. L., Chiappe, L. M., Fernandez-Jalvo, Y., Ortega, F., SanchezChillon, B., Poyato-Ariza, F. J., et al. (2001). An early Cretaceous pellet. Nature, 409, 998-1000.

Schweigert, G. (1999). Erhaltung und Einbettung von Belemniten im Nusplinger Plattenkalk (Ober-Kimmeridgium, Beckeri-Zone, Schwäbische Alb). Stuttgarter Beiträge zur Naturkunde, B, 273, 1-35.

Schweigert, G. (2018). Miscellanea aus dem Nusplinger Plattenkalk (Ober-Kimmeridgium, Schwäbische Alb). 19. Zwei Fallbeispiele besonderer Belemnitenerhaltung. Zwei Fallbeispiele besonderer Belemnitenerhaltung. Jahresberichte und Mitteilungen des oberrheinischen geologischen Vereins, N.F., 100, $509-516$

Schweigert, G., \& Dietl, G. (1999). Zur Erhaltung und Einbettung von Ammoniten im Nusplinger Plattenkalk (Oberjura, Südwestdeutschland). Stuttgarter Beiträge zur Naturkunde, B, 272, 1-31.

Scotese, C. R. (1997). Paleogeographic atlas, PALEOMAP Progress Report 90-0497. Department of Geology. Arlington: University of Texas.

Seilacher, A. (1998). Mosasaurs, limpets or diagenesis: How Placenticeras shells got punctured. Mitteilungen des Museums für Naturkunde Berlin, Geowissenschaftliche Reihe, 1, 93-102.

Tanabe, K., Misaki, A., Landman, N. H., \& Kato, T. (2013). The jaw apparatuses of Cretaceous Phylloceratina (Ammonoidea). Lethaia, 46, 399-408.

Thies, D., \& Hauff, R. B. (2012). A Speiballen from the Lower Jurassic Posidonia Shale of South Germany. Neues Jahrbuch für Geologie und Paläontologie Abhandlungen, 267, 117-124.

Tsujita, C. J., \& Westermann, G. E. G. (2001). Were limpets or mosasaurs responsible for the perforations in the ammonite Placenticeras? Palaeogeography, Palaeoclimatology, Palaeoecology, 169, 245-270.

Vallon, L. H. (2012). Digestichnias (Vialov, 1972)—an almost forgotten ethological class for trace fossils. New Mexico Museum of Natural History and Science, Bulletin, 57, 131-135.

Vullo, R. (2011). Direct evidence of hybodont shark predation on Late Jurassic ammonites. Naturwissenschaften, 98, 545-549.

Wendt, J. (1985). Disintegration of the continental margin of northwestern Gondwana: Late Devonian of the eastern AntiAtlas (Morocco). Geology, 13, 815-818.

Wendt, J. (1988). Facies pattern and paleogeography of the Middle and Late Devonian in the eastern Anti-Atlas (Morocco). In N. J. McMillan, A. F. Embry, \& D. J. Glass (Eds.), Devonian of the world. Canadian Society of Petroleum Geologists, Memoires, 14(1), 467-480.

Westermann, G. E. G. (1973). Strength of concave septa and depth limits of fossil cephalopods. Lethaia, 6, 383-403. 
Westermann, G. E. G. (1985). Exploding Nautilus camerae does not test septal strength index. Lethaia, 18, 348. https://doi.org/10. 1111/j.1502-3931.1985.tb00714.x.

Westermann, G. E. G., \& Ward, P. (1980). Septum morphology and bathymetry in cephalopods. Paleobiology, 6, 48-50. https://doi. org/10.1017/s0094837300012495.

Whitenack, L. B., Simkins, D. C., Jr., \& Motta, P. J. (2011). Biology meets engineering: The structural mechanics of fossil and extant shark teeth. Journal of Morphology, 272, 169-179.
Wings, O., \& Sander, P. M. (2007). No gastric mill in sauropod dinosaurs: New evidence from analysis of gastrolith mass and function in ostriches. Proceedings of the Royal Society, B, 274, 635-640. https://doi.org/10.1098/rspb.2006.3763.

Zangerl, R., \& Richardson, E. S. (1963). The paleoecological history of two Pennsylvanian black shales. Fieldiana Geology, Memoirs, 4, 1-352.

Zatoń, M., Villier, L., \& Salamon, M. A. (2007). Signs of predation in the Middle Jurassic of south-central Poland: Evidence from echinoderm taphonomy. Lethaia, 40, 139-151. 